\title{
On the pathogenesis trail: What marker B cell clones tell us about inflammatory bowel disease
}

\author{
JONATHAN BRAUN MD PhD, YADRIRA VALLES-AYOUB MD PhD, LINDA BERBERIAN PhD, \\ MARK EGGENA BS, LYNN K GORDON MD PhD, STEPHAN TARGAN MD
}

\begin{abstract}
J Braun, Y Valles-Ayoub, L Berberian, M Eggena, LK GORDON, S TARGAN. On the pathogenesis trail: What marker B cell clones tell us about inflammatory bowel disease. Can J Gastroenterol 1996;10(2):115-119. Clonal patterns of B cell activity have been recognized in inflammatory bowel disease, most notably in the immunogenetic relationship of perinuclearantineutrophil cytoplasmic antibodies to ulcerative colitis. Conceptually, this most likely reflects the B cell response to antigens predominating at these sites of mucosal inflammation. Identification of these $\mathrm{B}$ cell clones and their antigenic targets may be of pathogenetic and practical importance to diagnosis and treatment. The authors describe strategies to identify such clones, based on recent advances in the characterization and detection of antibody gene products. As an example of this strategy, a clonal detection system was used to identify new marker antibodies potentially useful in the laboratory diagnosis of Crohn's disease and ulcerative colitis. One surprising outcome of such studies is the unexpected and specific association of the B cell clonal response in Campylobacter jejuni enterocolitis and inflammatory bowel disease. By analogy to the pathogenetic role of Helicobacter pylori-induced mucositis in peptic ulcer disease, this evidence renews attention to the role of $\mathrm{C}$ jejuni in the initiation of ulcerative colitis and Crohn's disease.
\end{abstract}

Key Words: B lymphocyte, Crohn's disease, Phage display antibody, Ulcerative colitis

\section{À la recherche de la pathogenèse : ce que nous disent les clones marqueurs des cellules $B$ au sujet de la maladie inflammatoire de l'intestin}

\begin{abstract}
RÉSUMÉ : Les modes clonaux de l'activité des cellules B ont été reconnus dans la maladie inflammatoire de l'intestin, et de façon plus marquée dans le rapport immunogène des anticorps cytoplasmiques $\mathrm{p}$-antineutrophiles ( $\mathrm{p}$-ANCA) et de la colite ulcéreuse. Conceptuellement, cela reflète tout probablement la réponse des cellules $B$ aux antigènes prépondérants au siège de l'inflammation muqueuse. L'identification des clones de cellules B et de leur cible antigénique peut revêtir une importance pathogénétique et pratique pour le diagnostic et le traitement. Les auteurs décrivent les stratégies visant à identifier de tels clones sur la base des récents progrès accomplis en matière de caractérisation et de détection des produits des gènes des anticorps. À titre d'exemple de cette stratégie, un système de dépistage clonique a été utilisé pour identifier de nouveaux anticorps marqueurs potentiellement utiles pour le diagnostic en laboratoire de la maladie de Crohn et de la colite ulcéreuse. L'un des résultats surprenants de ces études est l'association spécifique inattendue de la réponse clonale des cellules B dans l'entérocolite à Campylobacter jejuni et dans la maladie inflammatoire de l'intestin. Par analogie au rôle pathogénétique de Helicobacter pylori dans la mucosite et l'ulcère gastroduodénal, cette observation ravive l'intérêt pour le rôle de C. jejuni dans le déclenchement de la colite ulcéreuse et la maladie de Crohn.
\end{abstract}

Departments of Pathology, Ophthalmology and Medicine, UCLA School of Medicine, and IBD Research Center, Cedars-Sinai Medical Center, Los Angeles, California, USA

Correspondence and reprints: Dr J Braun, Department of Pathology, UCLA School of Medicine, Los Angeles, CA 90024, USA. Telephone 310-825-0650, fax 310-206-0657, e-mail jbraun@pathology.medsch.ucla.edu

This paper was presented at the Basic Research and Clinical Implications in IBD meeting, April 6 to 9, 1994, held in Victoria, British Columbia. This paper has also been published in Sutherland LR, et al, eds. Inflammatory Bowel Disease: Basic Research, Clinical Implications and Trends in Therapy. Boston, Dordrecht and London: Kluwer Academic Publishers, 1994 
$\mathrm{T}$ he pathogenesis of Crohn's disease and ulcerative colitis is incompletely understood, but ultimately involves immune-mediated tissue damage. These diseases are associated with various immunological abnormalities, many of which are probably secondary to inflammation (1-5). CD4 $\mathrm{T}$ cells are widely believed to serve as key regulatory cells in tissue-destructive immune responses. In inflammatory bowel disease (IBD), the response occurs in a mucosal site interfacing with the intestinal lumen. Consequently an obvious source of target antigens is microbial products, although their role, and that of other lumenal or intrinsic mucosal cellular antigens, have yet to be established. A key step in the resolution of IBD pathogenesis and eventual treatment is resolution of the target antigens initiating the disease. Cells that most directly reveal the identity of these antigens are $\mathrm{T}$ cells. However, the low avidity of the $\mathrm{T}$ cell antigen receptor and the complicated peptide/major histocompatibility complex II structure of its natural ligand render these cells unsuitable for analytical studies of this important issue.

\section{DETECTING IMMUNE RESPONSE TARGET ANTIGENS WITH THE B LYMPHOCYTE}

In contrast, immunoglobulin, both in its membrane form as the B cell antigen receptor and as soluble antibody, is a high avidity receptor ideally suited for use in isolation and characterization of antigens. In vivo, $B$ cells have the predominant role of capturing antigens and creating the peptide/major histocompatibility complex II ligand ('antigen presentation') for the $\mathrm{T}$ cell antigen receptor (6). Moreover, in this role B cells may serve a pivotal immunological role in the abridgement of tolerance to self-antigens and in the activation of pathogenic $T$ cells (as suggested for the nonobese diabetic murine model of type I diabetes mellitus [7]).

Conversely, B cell activation and clonal expansion depend on interaction with $\mathrm{T}$ cells through antigen presentation. Thus, in sites of an immune response, $\mathrm{B}$ and $\mathrm{T}$ cells sharing the same antigenic specificity activate and expand in parallel. Consequently, if one can identify such selected B cells, their antibodies offer a tool to characterize the target antigen driving the immune response. Since preferential antigen presentation by $\mathrm{B}$ cells reflects the exceptional avidity of membrane immunoglobulin for specific antigen, the antibodies produced by at least a subgroup of $B$ cells in autoimmune lesions may actually identify the target antigen of the pathogenic $\mathrm{T}$ cell (Figure 1).

\section{ANTIBODIES AS DISEASE MARKERS AND THE 12-ANTINEUTROPHIL CYTOPLASMIC ANTIBODIES PARADIGM}

Certain immune-mediated disorders, such as systemic lupus erythematosus, primary biliary cirrhosis and chronic active hepatitis, are closely associated with distinctive patterns of autoantibodies. In IBD, various autoantibodies and antimicrobial antigens have been reported: lymphocytotoxic antibodies; antibodies specific for colonic epithelium, cytoplasmic neutrophil or endothelial antigens; certain erythro-

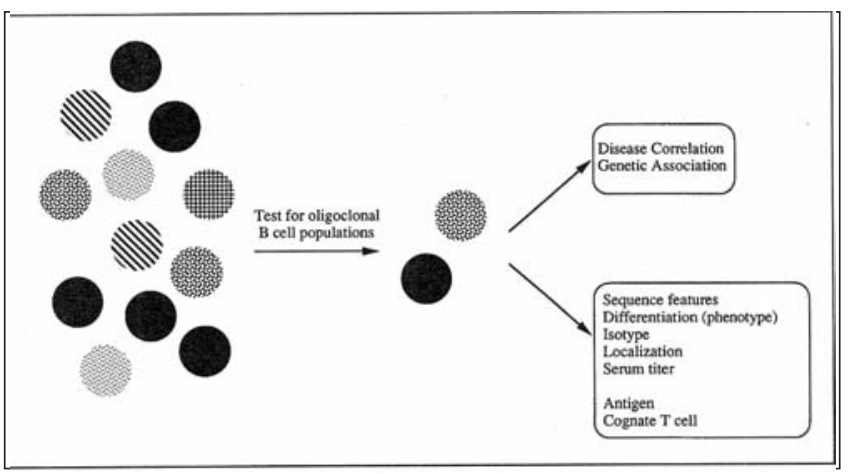

Figure 1) Proposed genesis of B cells expressing disease markers. In mucosal sites of an inflammatory bowel disease (IBD) lesion, immunological activity is regulated by 'autoreactive' $T$ cells specific for local target antigens (which may include food, microbial or intrinsic mucosal peptides). B cells expressing antibodies that share this specificity efficiently capture and present these antigens, resulting in their preferential activation by IBD T cells. Antibody secretion by these activated B cells is detected in serum by using adventitious cross-reactive antigens (antineutrophil cytoplasmic antibodies and antierythrocyte antibody)

\section{TABLE 1}

Marker antibodies in inflammatory bowel disease

\begin{tabular}{lcccc}
\hline Marker & $\begin{array}{c}\text { Ulcerative } \\
\text { colitis }\end{array}$ & $\begin{array}{c}\text { Crohn's } \\
\text { disease }\end{array}$ & $\begin{array}{c}\text { Disease } \\
\text { activity }\end{array}$ & $\begin{array}{c}\text { Reference } \\
16-18\end{array}$ \\
p-ANCA & +++ & \pm & - & $13-15$ \\
AEA-15 & + & +++ & - & 12 \\
Anti-HSP 70 & + & ++ & + & 11 \\
AECA & ++ & + & + & + \\
Anti-42 kDa & +++ & - & + & 12 \\
\hline
\end{tabular}

AEA-15 Antierythrocyte VH3-15 antibody; AECA Antiendothelial cell antibody; HSP Heat shock protein; p-ANCA Perinuclear-antineutrophil cytoplasmic antibodies

cyte membrane proteins; and bacterial heat shock proteins (8-18) (Table 1). These marker antibodies are unlikely to be directly pathogenic, although interesting evidence for this role has been presented in the case of a $42 \mathrm{kDa}$ colonic epithelial antigen (11). However, marker antibodies have demonstrated importance for several other reasons. First, from the practical standpoint, their disease specificity makes them useful tools for diagnostic purposes. Second, the serum levels of some antibodies correlate with disease activity, and thus may be useful in titrating or modifying treatment regimens. Finally, from the conceptual standpoint, these markers may represent the antibodies produced by activated $\mathrm{B}$ cells in sites of disease-specific immune response. If so, their avidity for 'laboratory' antigens (eg, cytoplasmic neutrophil or endothelial components) is likely to reflect a serendipitous but idiosyncratic cross-reactivity.

One marker antibody, perinuclear-antineutrophil cytoplasmic antibodies ( $\mathrm{p}$-ANCA), provides a revealing example relating the marker $B$ cell clone to immunobiology of the underlying disease. Elevated serum levels of p-ANCA are a sensitive marker for individuals with ulcerative colitis. The marker is specific for this disease process because it is not 

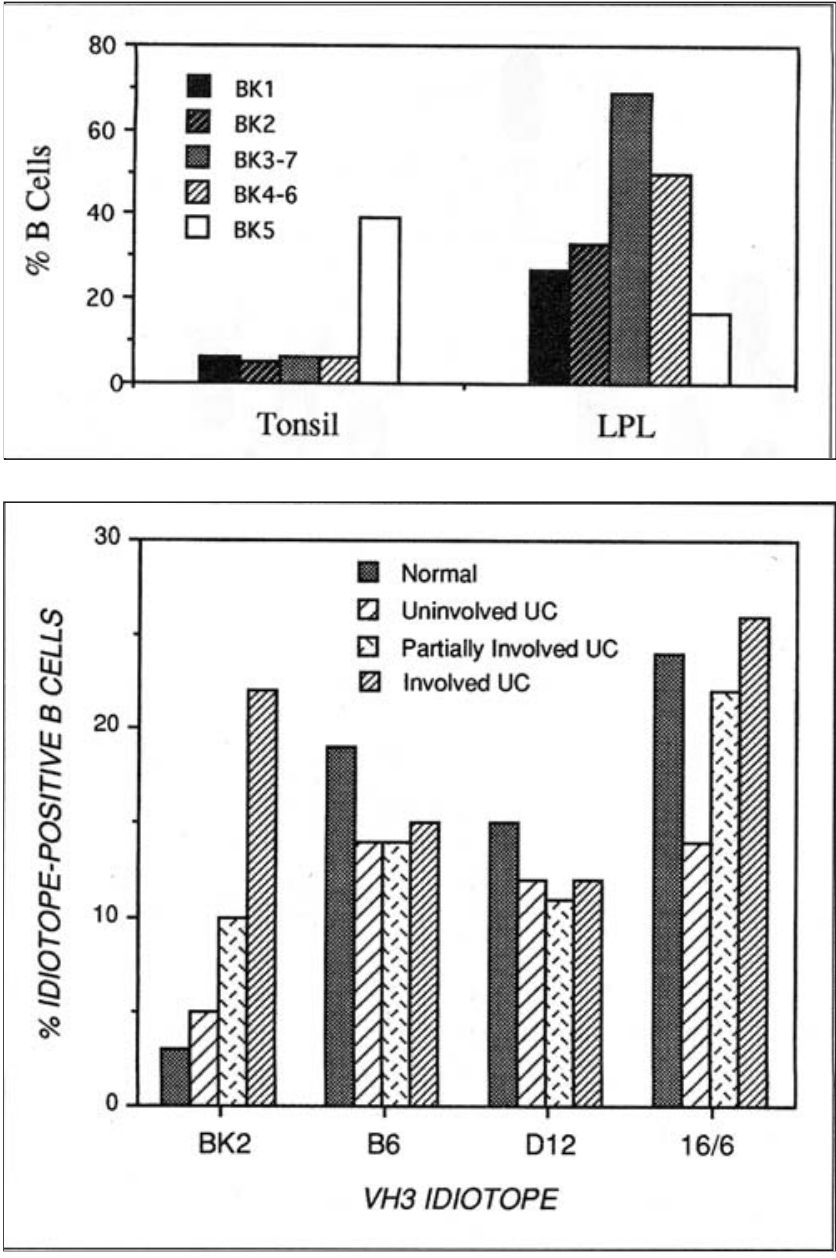

Figure 2) Abundance of VH3 idiotope positive lamina propria lymphocyte (LPL) B cells in normal and ulcerative colitis (UC). Lamina propria mononuclear cells were isolated from endoscopic colonic biopsies and stained with fluorescent antibodies for CD19 (a pan-B cell marker) and anti-idiotope reagents specific for various $V H$ genes. Top Frequency of $B$ cells expressing various BK anti-idiotopes (specific for various VH3 family epitopes) in tonsil and colonic LPL. Bottom Frequency of B cells expressing VH3 family idiotopes: B6 and D12 (anti-VH3-30); 16/6 (anti-VH3-23); BK2 (anti-VH3-15)

observed in individuals with a variety of other acute and chronic colitidies. Serum titres of ANCA are elevated regardless of clinical status, and are thus not useful for monitoring disease activity. However, while individuals with elevated p-ANCA are rare among healthy children and adults, an elevated frequency is observed among healthy relatives of ulcerative colitis patients and in those with the related syndrome of sclerosing cholangitis. Thus, p-ANCA is hypothesized to reflect an immunogenetic susceptibility trait for ulcerative colitis. This idea is supported by the unique human leukocyte antigen-D alleles associated with p-ANCA-positive individuals with ulcerative colitis (and the uncommon p-ANCA-positive Crohn's disease subset) (18). It thus appears that secretory B cells expressing pANCA may be closely associated with the genetic predisposition and primary immunopathophysiology of ulcerative colitis.

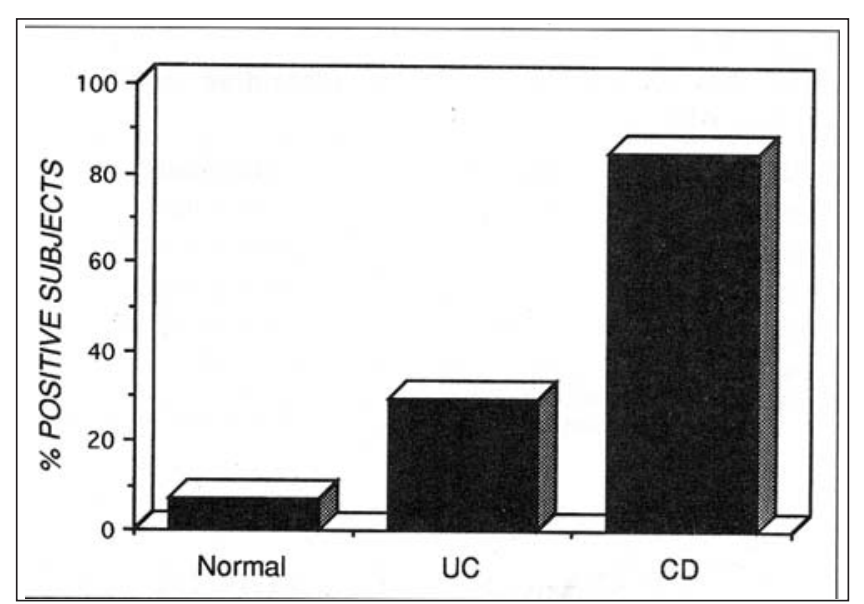

Figure 3) Antierythrocyte VH3-15 antibody (AEA-15) levels in inflammatory bowel disease. Sera from individuals with ulcerative colitis (UC), Crohn's disease (CD) or healthy adults were tested by ELISA for AEA-15 levels, and the frequency of positive sera in each group were tabulated ( $n=27$ for each group)

\section{DISTINCTIVE CLONAL B CELL POPULATIONS IN NORMAL AND ULCERATIVE COLITIS LAMINA PROPRIA}

The most logical place to find distinctive clonal B cell populations is in the mucosal lesion, which in both Crohn's disease and ulcerative colitis is associated with abundant B cells (many at the plasma cell stage). Intralesional B cells are notable for high frequency of immunoglobulin (Ig) G expression, skewed towards IgG2 and IgG1 subclasses in Crohn's disease and ulcerative colitis, respectively (4). These IgG subclass patterns may largely reflect the immunoregulatory action of a distinct pattern of local lymphokine production and activity of the corresponding $\mathrm{T}$ cell subpopulations. Clonal characterization of these intralesional $\mathrm{B}$ cells has been previously limited to Southern blot analysis, which has shown that these subpopulations are not mono- or oligoclonal (19).

Using a set of reagents (anti-idiotopes) that detect specific antibody $\mathrm{VH}$ genes, we had the opportunity to readdress the frequency of B cell clonal subsets in blood and colonic lamina propria B cells (Figure 2, top). Compared with the blood $\mathrm{B}$ cell population, cells in the mucosa are distinguished by their profile of $\mathrm{VH}$ gene idiotopes. While the basis of these differences remains to be established, they presumably reflect selection by the unique set of microbial and food antigens accumulated in the colonic mucosa. These clonal parameters have also been used to compare mucosal B cells from ulcerative colitis patients with those from patients with different levels of disease activity (Figure 2, bottom). Interestingly, while several clonal B cell subsets remain unchanged, those using the BK2 idiotope (defining the VH315 gene) appear to be selectively expanded. One simple explanation for this finding is that these $\mathrm{VH} 3-15$ antibodies share specificity for the target antigen driving the ulcerative colitis-associated inflammatory response. 
TABLE 2

Candidate diagnostic panel for ulcerative colitis and Crohn's disease

\begin{tabular}{|c|c|c|}
\hline p-ANCA & AEA-15 & Diagnosis \\
\hline Positive & Negative & Non-IBD \\
\hline Positive & Negative & Ulcerative colitis \\
\hline Negative & Positive & Crohn's disease \\
\hline Positive & Positive & Mixed IBD \\
\hline
\end{tabular}

Antierythrocyte $\mathrm{VH} 3-15$ antibody (AEA-15) and perinuclear-antineutrophil cytoplasmic antibody ( $p$-ANCA) levels in patient sera are tested by a standard microtitre plate enzyme-linked immunoassay. IBD Inflammatory bowel disease

\section{THE AEA-15 MARKER ANTIBODY: TOWARDS A LABORATORY DIFFERENTIAL DIAGNOSIS OF IBD}

Since VH3-15 antibodies appear to be informative for ulcerative colitis-related inflammation, we recently searched for corresponding cross-reactive autoantibodies that could serve as serum disease-specific markers (20). Individuals with ulcerative colitis were found to express an antierythrocyte $\mathrm{VH}$-15 antibody commonly, designated AEA-15, reactive with a novel erythrocyte membrane protein. Like with $\mathrm{p}$-ANCA, presence of the antibody was not related to disease activity and was detectable even in postcolectomy ulcerative colitis patients. Further investigation revealed an even higher frequency and titre of this antibody in individuals with Crohn's disease (Figure 3). This marker antibody was selective for IBD because it was rarely observed in healthy individuals or in those with other forms of inflammatory or infectious colitis. An unexpected and interesting exception was Campylobacter jejuni enterocolitis, in which the marker antibody was also prevalent (20).

There are two implications of this finding. First, AEA-15 represents a new serum marker for a novel subset of inflammatory colidities, notably Crohn's disease. Moreover, initial studies comparing AEA-15 with p-ANCA reveal that they are independent parameters. As a combined set of markers, they may thus allow a tool for provisional laboratory diagnosis of ulcerative colitis versus Crohn's disease (Table 2). Second, the association of $C$ jejuni with IBD is provocative from the standpoint of IBD pathogenesis. Work of the past few years has advanced the concept of microbial pathogens as initiating agents in chronic mucosal inflammation (notably, Helicobacter pylori in peptic ulcer disease [21]). This paradigm prompts the hypothesis that $\mathrm{C}$ jejuni has a similar pathogenic role in IBD, and that individuals with ulcerative colitis and Crohn's disease are distinguished from controls by immunogenetic traits that cause inefficient resolution of this bacterial infection and that cause inflammatory responses to it which are necrotizing and granulomatous, respectively. While the presence of conventional active $\mathrm{C}$ jejuni infection has been refuted by a careful study of Blaser and colleagues (22), the role of this pathogen deserves reevaluation in this new context of pathogenesis.

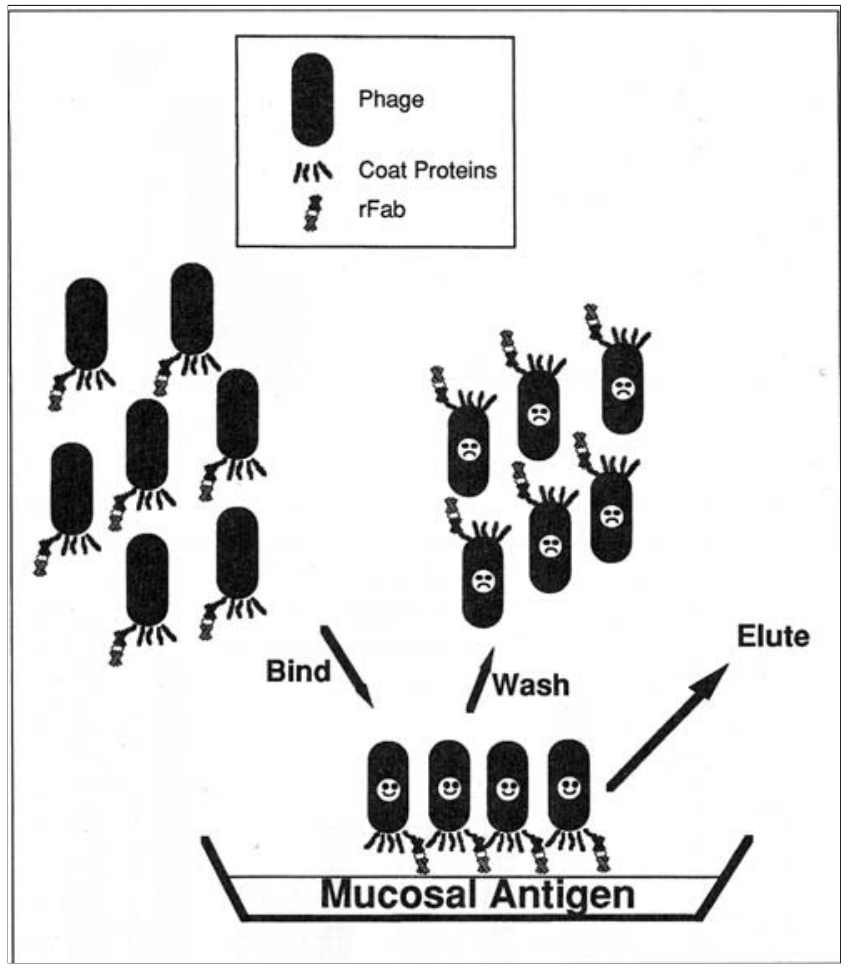

Figure 4) Strategy for selection of phage expressing recombinant antibodies $(r \mathrm{Fab})$ on microwells coated with mucosal antigen

\section{STRATEGIES ON THE HORIZON}

The preceding examples reflect some of the opportunities presented by systematic analysis of clonal B cell activity in IBD. Thus far such clonal B cell analysis is restricted to direct studies of antibody $\mathrm{V}$ gene usage at the nucleic acid level or to detection with the relatively small number of anti- $\mathrm{V}$ gene reagents. Conceptually, a much more ideal approach would be to evaluate comprehensively lesional B cells for those reactive with disease-specific target antigens. Recently, the technology for such investigation has appeared in the form of phage display antibody libraries (23). Using small amounts of RNA (obtainable even from endoscopic biopsy specimens), recombinant methods allow the creation of libraries of cloned antibody genes, in which each antibody gene is not only carried by the phage vector, but also expressed as part of its coat protein. The power of this system is that complete libraries of antibodies representative of a B cell population can be readily created and rapidly selected by direct binding to mucosal antigens (Figure 4). By using this technology, it is - for the first time feasible to select and characterize comprehensively the antibody repertoire of lesional B cells. There is much activity in the autoimmunity field to identify representative lesional antibodies and to use them in search of pathogenic antigenic targets of the disease-specific immune response. The outcome of such research will be an important test of this concept of autoimmune pathogenesis and, if successful, a source of candidate antigens for disease-specific immune therapies. 
ACKNOWLEDGEMENTS: Supported by NIH grants DK46763 and CA12800, and the Crohn's and Colitis Foundation.

\section{REFERENCES}

1. Tan EM. Autoantibodies in pathology and cell biology. Cell 1991;67:841-2

2. Strober W, James SP. The immunologic basis of inflammatory bowel disease. J Clin Immunol 1986;6:414-32.

3. Targan SR, Kagnoff MF, Brogan MD, Shanahan F. Immunologic mechanisms in intestinal diseases. Ann Intern Med 1987;106:853-70.

4. MacDermott RP, Stenson WF. Alterations of the immune system in ulcerative colitits and Crohn's disease. Adv Immunol 1988;42:285-328.

5. Kagnoff MF. A question of balance: Ups and downs of mucosal inflammation. J Clin Invest 1994;94:1.

6. Mamula MJ, Fatenejad S, Craft J. B cells process and present lupus autoantigens that initiate autoimmune $\mathrm{T}$ cell responses. J Immunol 1994;152:1453-61.

7. Lin R-W, Mamula MJ, Hardin JA, Janeway CA. Induction of autoreactive B cells allows priming of autoreactive T cells. J Exp Med 1991;173:1433-9.

8. Korsmeyer SJ, Williams RC Jr, Wilson AO, Strickland RG. Lymphocytotoxic antibody in inflammatory bowel disease. A family study. N Engl J Med 1975;293:1117-20.

9. Lagercrantz R, Perlmann P, Hammarstrom S. Immunological studies in ulcerative colitis. V. Family studies. Gastroenterology 1971;60:381-9.

10. Fiocchi C, Roche JK, Michener WM. High prevalence of antibodies to intestinal epithelial antigens in patients with inflammatory bowel disease and their relatives. Ann Intern Med 1989;110:786-94.

11. Das KM, Vecchi M, Sakamaki S. A shared and unique epitope(s) on human colon, skin, and biliary epithelium detected by a monoclonal antibody. Gastroenterology 1990;98:464-9.

12. Stevens TR, Harley SL, Groom JS, et al. Anti-endothelial cell antibodies in inflammatory bowel disease. Dig Dis Sci 1993;38:426-32.

13. Lindberg E, Magnusson KE, Tysk C, Jarnerot G. Antibody (IgG, IgA, and IgM) to baker's yeast (Saccharomyces cerevisiae), yeast manna, gliadin, ovalbumin, and betalactoglobulin in monozygotic twins with inflammatory bowel disease. Gut 1992;33:909-13.

14. O'Mahony S, Anderson N, Nuki G, Ferguson A. Systemic and mucosal antibodies to klebsiella in patients with ankylosing spondylitis and Crohn's disease. Ann Rheum Dis 1992:51:1296-300.

15. Elsaghier A, Prantera C, Moreno C, Ivanyi J. Antibodies to Mycobacterium paratuberculosis-specific protein antigens in Crohn's disease. Clin Exp Immunol 1992;90:503-8.

16. Saxon A, Shanahan F, Landers C, Ganz T, Targan S. A distinct subset of antineutrophil cytoplasmic antibodies is associated with inflammatory bowel disease. J Allergy Clin Immunol 1990;86:202-10.

17. Duerr RH, Targan SR, Landers CJ, Sutherland LR, Shanahan F. Anti-neutrophil cytoplasmic antibodies in ulcerative colitis. Comparison with other colitides/diarrheal illnesses. Gastroenterology 1991;100:1590-6.

18. Yang H, Rotter JI, Toyoda H, et al. Ulcerative colitis: A genetically heterogeneous disorder defined by genetic (HLA class II) and subclinical (antineutrophil cytoplasmic antibodies) markers. J Clin Invest 1993;92:1080-4.

19. Kaulfersch W, Fiocchi C, Waldmann TA. Polyclonal nature of the intestinal mucosal lymphocyte populations in inflammatory bowel disease. A molecular genetic evaluation of immunoglobulin and T-cell antigen receptors. Gastroenterology 1988;95:364-70.

20. Berberian LS, Valles-Ayoub Y, King L, Gordon LK, Targan SR, Braun $\mathrm{J}$. Expression of a novel autoantibody defined by the VH3-15 gene in inflammatory bowel disease and Campylobacter jejuni enterocolitis. J Immunol 1994;153:3756-63.

21. Graham DY. Campylobacter pylori and peptic ulcer disease. Gastroenterology 1989;96:615.

22. Blaser MJ, Hoverson D, Ely IG, Juncan DJ, Wang WL, Brown WR. Studies of Campylobacter jejuni in patients with inflammatory bowel disease. Gastroenterology 1984;86:33-8.

23. Persson MA, Caothien RH, Burton DR. Generation of diverse high-affinity human monoclonal antibodies by repertoire cloning. Proc Natl Acad Sci USA 1991;88:2432-6. 


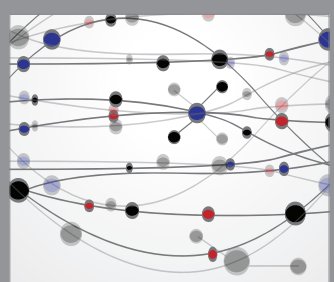

The Scientific World Journal
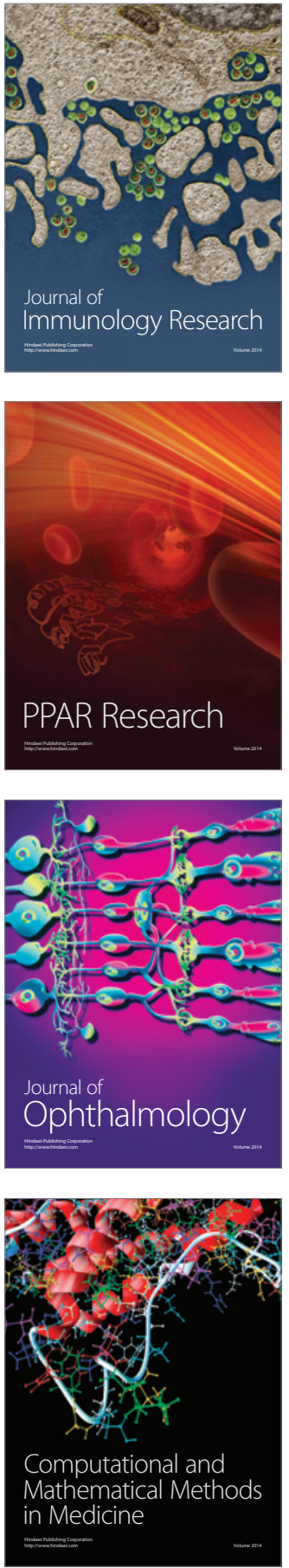

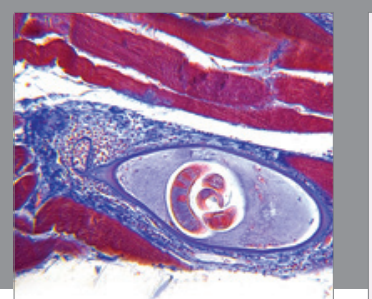

Gastroenterology Research and Practice

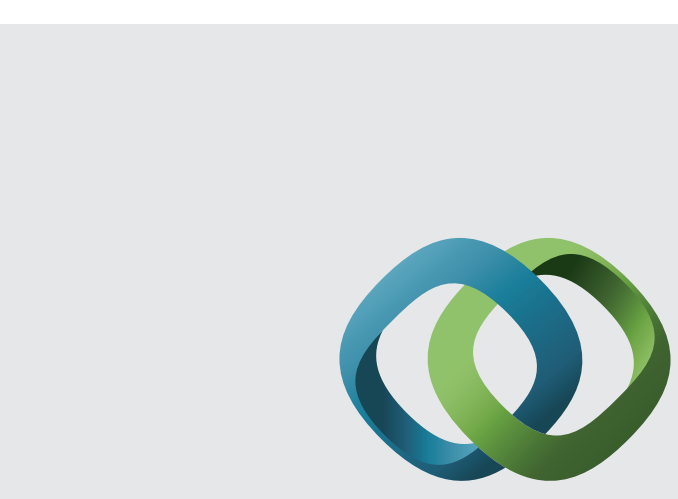

\section{Hindawi}

Submit your manuscripts at

http://www.hindawi.com
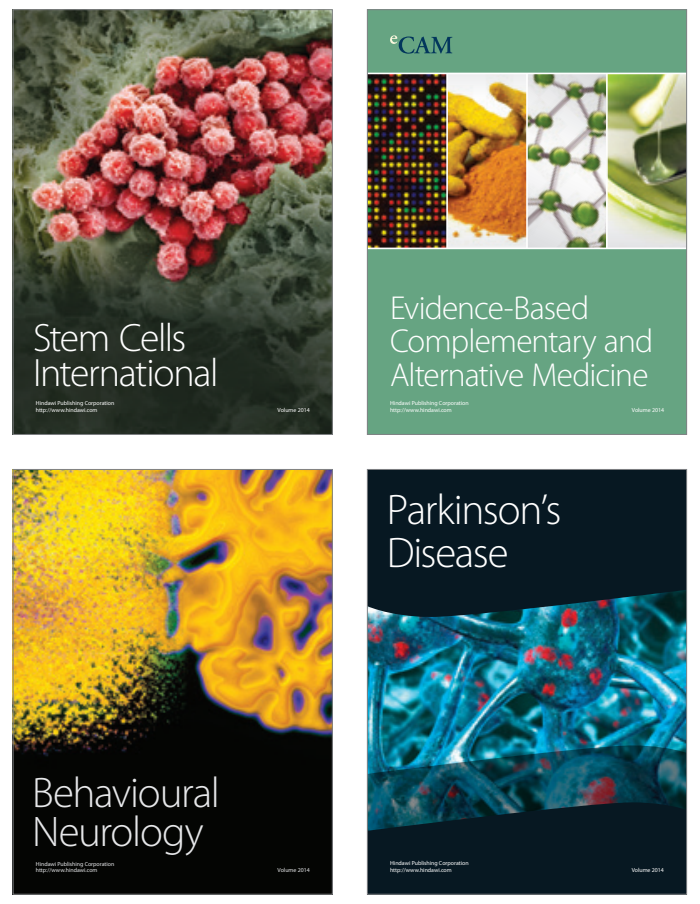
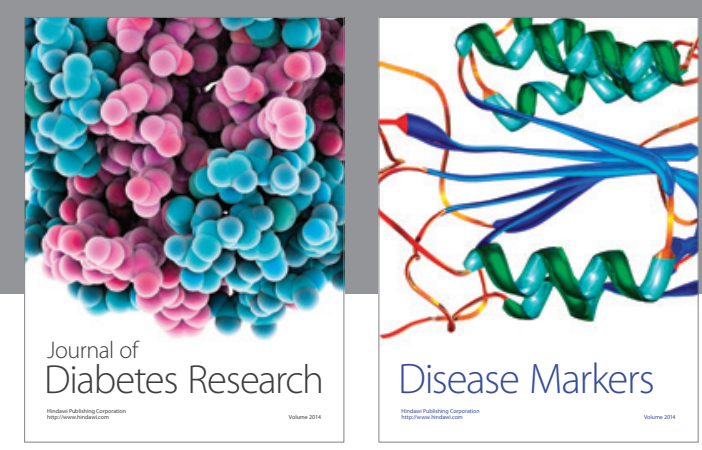

Disease Markers
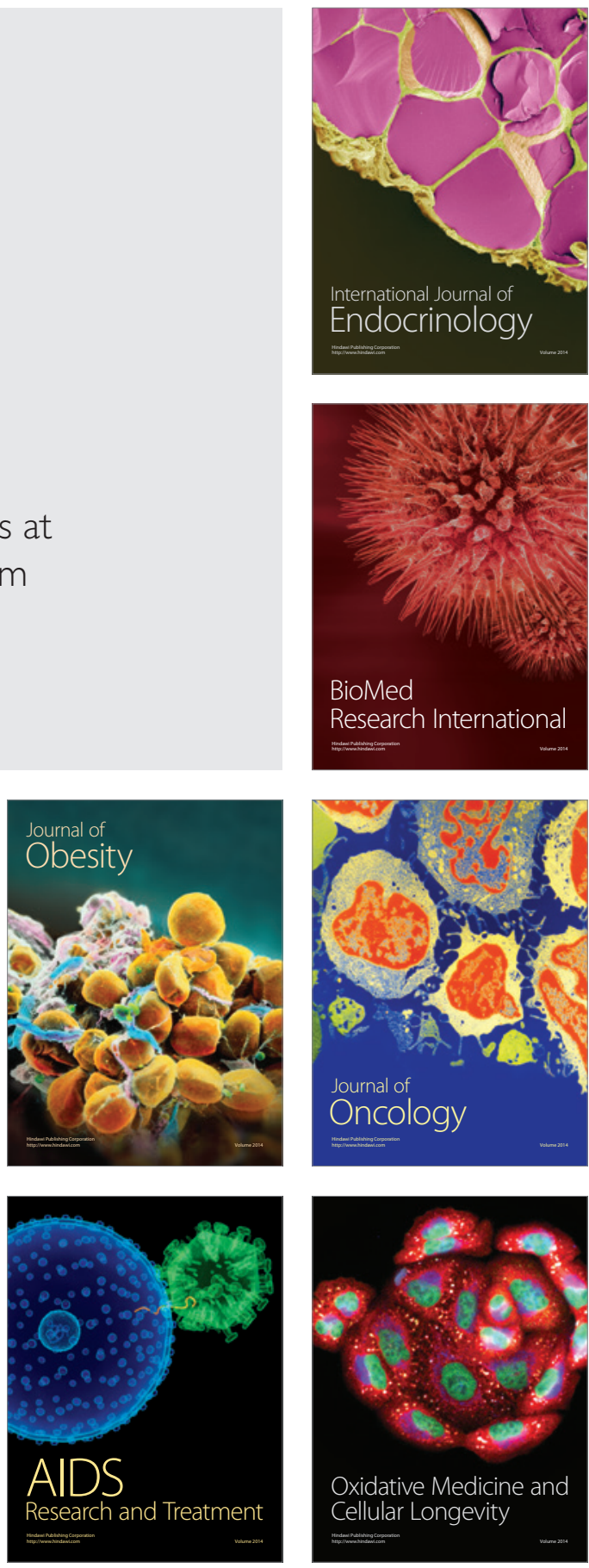